\title{
UJI AKTIVITAS ANTIBAKTERI POLIEUGENOL BERAT MOLEKUL TINGGI DENGAN PENAMBAHAN EKSTRAK DAUN PALA (Myristica fragrans Houtt)
}

\section{[Antibacterial Activity Test of High Molecular weight Polyeugenol with an addition of Nutmeg Leaf Extract (Myristica fragrans Houtt)]}

\author{
Misba Anggriani ${ }^{\star *}$, Erwin Abdul Rahim ${ }^{1}$, Syamsuddin ${ }^{1}$ \\ 1) Jurusan Kimia, Fakultas MIPA, Universitas Tadulako \\ Jl. Soekarno Hatta, Kampus Bumi Tadulako Tondo Palu, Telp. 0451- 422611 \\ *)Corresponding Author: misbanggriani@gmail.com, hp. 082197243338
}

Diterima 17 April 2018, Disetujui 8 Agustus 2018

\begin{abstract}
The antibacterial test of polyeugenol with an addition of nutmeg leaf extract against Staphylococcus aureus and Escherichia coli has been done. Polyeugenol has been synthesized from eugenol by using cationic polymerization with the ratio of eugenol concentration to $\mathrm{H}_{2} \mathrm{SO}_{4}-\mathrm{CH}_{3} \mathrm{COOH}$ catalyst of $4: 1$. The result showed that polyeugenol was solid, brown and had molecular weight of $2.18 \times 10^{7}$ $\mathrm{g} / \mathrm{mol}$. Investigation of antibacterial activity and its combination with leaf nutmeg extract was done using agar well-diffusion method. The concentration of combined both substances were varied to $1 \%$ $2 \% 3 \% 4 \%$ and $5 \%(\mathrm{w} / \mathrm{v})$. The result showed that antibacterial activity was observed in Staphylococcus aureus at concentration of $1 \% 2 \% 3 \% 4 \%$ and $5 \%$ with inhibition zone of $15.06 \mathrm{~mm}$, $16.93 \mathrm{~mm}, 18.51 \mathrm{~mm}, 19.69 \mathrm{~mm}$ and $20.99 \mathrm{~mm}$, respectively, whereas for Escherichia coli was at concentration of $1 \% 2 \% 3 \% 4 \%$ and $5 \%$ with inhibition zone of $17.5 \mathrm{~mm}, 18.22 \mathrm{~mm}, 18.90 \mathrm{~mm}, 19.05$ $\mathrm{mm}$ and $19.45 \mathrm{~mm}$, respectively. Our findings suggested that inhibition effect of polyeugenol decreased in Staphylococcus aureus after the addition of nutmeg leaf extract, meanwhile it insignificantly increased in Escherichia coli
\end{abstract}

Keywords : Polyeugenol, leaf nutmeg extract, antibacterial

\begin{abstract}
ABSTRAK
Telah dilakukan uji aktivitas antibakteri polieugenol dengan penambahan ekstrak daun pala terhadap bakteri Staphylococcus aureus dan Escherichia coli. Polieugenol disintesis melalui metode polimerisasi kationik menggunakan katalis $\mathrm{H}_{2} \mathrm{SO}_{4}-\mathrm{CH}_{3} \mathrm{COOH}$ dengan perbandingan 4 : 1. Polieugenol yang dihasilkan memiliki berat molekul sebesar $2.18 \times 10^{7} \mathrm{~g} / \mathrm{mol}$, berbentuk padat dan berwarna coklat. Pengujian aktivitas antibakteri campuran polieugenol dan ekstrak daun pala menggunakan metode difusi sumur. Konsentrasi campuran polieugenol dan ekstrak daun pala divariasikan: $1 \% 2 \%$ $3 \% 4 \%$ dan $5 \%(\mathrm{~b} / \mathrm{v})$. hasil pengujian menunjukkan bahwa campuran polieugenol dan ekstrak daun pala mempunyai aktivitas antibakteri terhadap Staphylococcus aureus pada konsentrasi $1 \% 2 \% 3 \%$ $4 \%$ dan $5 \%$ berturut-turut sebesar $15,06 \mathrm{~mm}, 16,93 \mathrm{~mm}, 18,51 \mathrm{~mm}, 19,69 \mathrm{~mm}$, dan 20,99 mm. sedangkan pada Escherichia coli nilai daya hambat yang dihasilkan berturut-turut sebesar $17,5 \mathrm{~mm}$, $18,22 \mathrm{~mm}, 18,90 \mathrm{~mm}, 19,05 \mathrm{~mm}$ dan $19,45 \mathrm{~mm}$. nilai daya hambat yang dihasilkan polieugenol pada Staphylococcus aureus setelah penambahan ekstrak daun pala mengalami penurunan, sedangkan pada Escherichia coli terjadi peningkatan nilai daya hambat yang tidak signifikan.
\end{abstract}

Kata Kunci : Polieugenol, Ekstrak Daun Pala, Antibakteri 


\section{LATAR BELAKANG}

Senyawa antibakteri memiliki manfaat untuk mengendalikan pertumbuhan bakteri yang merugikan atau patogen sehingga dapat mencegah penyebaran penyakit dan infeksi dan mencegah timbulnya pembusukan ataupun kerusakan bahan akibat bakteri (Sulistyo,1971). Menurut Pelczar dan Chan (1988) Mekanisme penghambatan Pertumbuhan bakteri dapat dihambat oleh senyawa antibakteri dengan cara merusak dinding sel sehingga terjadi perubahan permeabilitas membran sitoplasma bakteri yang menyebabkan keluarnya suatu bahan makanan dari dalam sel, mengubah bentuk molekul protein dan asam nukleat, menghambat kerja enzim, dan menghambat proses sintesis asam nukleat dan protein.

Bakteri patogen yang biasanya menginfeksi manusia, yaitu Escherichia coli dan Staphylococcus aureus. Staphylococcus aureus merupakan jenis bakteri penyebab infeksi piogenik pada manusia dan paling sering terjadi, seperti kasus sepsis pada luka bedah, mata lengket, lesi-lesi kulit pada bayi dan absis payudara. Sementara itu, Escherichia coli adalah jenis bakteri yang dapat menyebabkan infeksi pada saluran kencing, meningitis pada bayi, peritonitis, gastroenteritis, infeksi luka, kolesistitis, dan syok bakteremia (Gibson, 1996). Masyarakat umum mengobati penyakit yang disebabkan oleh bakteri biasanya menggunakan antibiotik seperti tetrasilkin, ampisilin yang keberadaannya mudah didapatkan, tetapi apabila digunakan dalam jangka waktu panjang dapat menyebabkan kegagalan dalam proses pengobatan berbagai jenis penyakit infeksi dikarenakan dapat menimbulkan resistensi terhadap antibiotik tersebut, sehingga diperlukan bahan alami sebagai alternatif pengobatan (Josodiwondo et al., 1996).

Salah satu bahan alam yang dapat dimanfaatkan sebagai antibakteri adalah ekstrak daun pala. Daun pala (Myristica fragrans Houtt) diperoleh dari tanaman pala yang merupakan tanaman rempah (Nurdjannah, 2007). Selain daunnya, minyak pala juga dapat dimanfaatkan sebagai inteksida, fungisida dan antibakteri (Nurdjannah, 2007). Ginting (2013) melaporkan bahwa tanaman pala terbukti mempunyai aktivitas antibakteri dimana ekstrak etil asetat yang dihasilkan dari daun pala mempunyai aktivitas antibakteri terhadap Staphylococcus aureus dan Escherichia coli. Selain itu pada konsentrasi hambat tumbuh minimum (KHTM) minyak atsiri daun pala sebesar 3,125\% menghasilkan zona hambat sebesar 16,81 $\mathrm{mm}$ terhadap Staphylococcus aureus, sedangkan pada Escherichia coli dengan konsentrasi minyak atsiri daun pala sebesar $1 \%$ menghasilkan zona hambat sebesar 0,54 mm (Rastuti et al., 2013).

Selain daun pala bahan alami yang juga dapat digunakan sebagai antibakteri yaitu eugenol (Agusta, 2000). 
Eugenol dapat diisolasi dari minyak cengkeh karena merupakan penyusun utamanya dengan kadar sekitar 80\%. Eugenol yang memiliki gugus fungsi alil, metoksi, dan hidroksi dapat ditingkatkan nilai jualnya dengan berbagai modifikasi, seperti diubah menjadi senyawa polieugenol dan isoeugenol (Sastrohamidjojo, 1981). Hikmah (2017) mensintesis eugenol menggunakan katalis $\mathrm{H}_{2} \mathrm{SO}_{4}-\mathrm{CH}_{3} \mathrm{COOH}$ dengan perbandingan 4 : 1 menghasilkan polieugenol dengan berat molekul tinggi. Polieugenol juga memiliki efek antibakteri terhadap bakteri Staphylococcus aureus yang menghasilkan diameter zona hambat untuk konsentrasi $0,01 \mathrm{~g} / \mathrm{mL}, 0,02 \mathrm{~g} / \mathrm{mL}$, dan $0,04 \mathrm{~g} / \mathrm{mL}$ berturut-turut sebesar 15,$72 ; 17,28$ dan $20,51 \mathrm{~mm}$, sedangkan pada Escherichia coli tidak ada efek antibakteri yang dihasilkan (Saputra, 2016).

Berdasarkan uraian diatas efek antibakteri yang dihasilkan polieugenol hanya pada bakteri Staphylococcus aureus, tetapi tidak terdapat efek pada bakteri E.coli, sedangkan untuk daun pala memiliki efek antibakteri yang baik terhadap Staphylococcus aureus dan Escherichia coli, sehingga untuk menghasilkan efek antibakteri yang baik pada polieugenol, maka perlu dilakukan kombinasi terhadap kedua bahan alami tersebut. Pada penelitian Indrasti et al. (2012) telah melakukan kombinasi antara kitosan dan ekstrak pala untuk menekan pertumbuhan bakteri Eschericia coli dan Salmonella thypii pada filet kakap merah yang memiliki nilai yang lebih besar dari pada diameter penghambatan kitosan atau ekstrak pala jika digunakan secara terpisah. Sehingga kombinasi polieugenol dan ekstrak daun pala juga dapat digunakan sebagai bahan anti bakteri dengan harapan agar dapat menekan pertumbuhan bakteri patogen. Sehingga diperlukan penelitian lebih lanjut mengenai uji aktivitas antibakteri polieugenol bobot molekul tinggi dengan penambahan ekstrak daun pala (Myristica fragrans Houtt).

\section{METODE PENELITIAN}

\section{Bahan dan Peralatan}

Bahan dasar yang digunakan dalam penelitian ini adalah biakan bakteri Escherichia coli dan staphylococcus aureus, Daun Pala, Eugenol 99,9\% (Happy Green), akuades, $\mathrm{H}_{2} \mathrm{SO}_{4}$ p.a, DMSO p.a, $\mathrm{CH}_{3} \mathrm{COOH} 4 \%$, metanol, Media pada agar NA, aluminium foil dan kertas saring.

Peralatan yang digunakan berupa magnetik stirrer, blender, ayakan 60 mesh, hot plate, inkubator (ESCO Class II BSC), autoklaf (Hirayama), mikropipet, neraca analitik, Rotary vakum evaporator, Penyaring buchner, Vortex, Bunsen, jangka sorong, ose bulat, Viskometeer Ostwald, Corong pisah, botol semprot dan alat-alat gelas lainnya yang umum digunakan dalam laboratorium kimia. 


\section{Prosedur Penelitian}

Sintesis Polieugenol (Suirta, 2012 dan Sudarlin dan Haryadi, 2015)

Mengambil 10 gram eugenol, lalu memasukkan ke dalam gelas kimia $250 \mathrm{~mL}$ kemudian menambahkan 2,5 mL larutan $\mathrm{H}_{2} \mathrm{SO}_{4}-\mathrm{CH}_{3} \mathrm{COOH}$ dengan perbandingan 4:1 (monomer : katalis) sambil terus diaduk menggunakan magnetik stirrer. Penambahan katalis dilakukan sedikit demi sedikit. Terbentuknya polimer ditandai dengan keluarnya asap putih pekat dan polimer melekat pada dinding gelas kimia. Polimerisasi dihentikan dengan menambahkan 4 tetes methanol pada campuran sehingga polimer mengental dan keras. Mendiamkan polimer pada suhu ruang selama 24 jam hingga polimer memadat dan kering. Perlakuan dilakukan dengan menggunakan konsentrasi asam asetat $4 \%$ dalam campuran katalis.

Pemurnian Polieugenol (Suirta, 2012 dan Sudarlin dan Haryadi, 2015)

Polieugenol yang telah terbentuk dilarutkan menggunakan dietil eter sebanyak $50 \mathrm{~mL}$ dan dikocok hingga larut. Setelah itu, dimasukkan ke dalam corong pisah $500 \mathrm{~mL}$ dan ditambahkan aquadest $100 \mathrm{~mL}$, dikocok kuat dan didiamkan selama 1 malam hingga terbentuk dua lapisan. Lapisan bagian bawah dibuang dan lapisan bagian atas berupa polieugenol yang tidak larut dalam air dicuci sebanyak 3 kali menggunakan akuades. Polieugenol yang larut dalam eter di pekatkan menggunakan rotary vakum evaporator untuk menghilangkan pelarut dietil eter. Untuk membebaskan kemungkinan adanya air yang terdapat pada polieugenol, maka polieugenol disaring menggunakan corong kaca dengan melewatkan pada 1 gram $\mathrm{Na}_{2} \mathrm{SO}_{4}$ anhidrat.

\section{Penentuan Berat Molekul Polieugenol (Ngadiwiyana, 2005)}

Sebanyak 1 gram polieugenol dilarutkan dalam etanol hingga konsentrasinya $0,02 \mathrm{~g} / \mathrm{mL}$ dalam labu takar $50 \mathrm{~mL}$. kemudian dibuat variasi konsentrasi polimer melalui pengenceran dengan etanol: $\quad 0,01500 \mathrm{~g} / \mathrm{mL}$; $0,01000 \mathrm{~g} / \mathrm{mL} ; \quad 0,00500 \quad \mathrm{~g} / \mathrm{mL}$; $0,00250 \mathrm{~g} / \mathrm{mL} ; \quad$ dan $0,00125 \mathrm{~g} / \mathrm{mL}$. dilakukan pengukuran waktu alir pelarut murni yaitu etanol dan masing-masing konsentrasi larutan polimer dengan menngunakan viscometer Ostwald, sehingga diperoleh $t_{0}, t_{1}, t_{2}, t_{3}, t_{4}, t_{5}$ dan $t_{6}$. Dengan persamaan Poisseuille diperoleh Пsp /C lawan C. dari kurva diekstrapolasi ke konsentrasi (C) sama dengan nol diperoleh [П]. Dengan persamaan MerkHouwink dihitung berat molekul dari polimer dengan menggunakan harga $\mathrm{K}$ dan a yang sesuai.

\section{Tahap Pengolahan Daun Pala}

Daun pala dicuci bersih, lalu mengeringkan daun pala dibawah sinar matahari, daun pala yang telah kering kemudian diblender hingga halus, lalu diayak dengan ayakan 60 mesh untuk mendapatkan tepung daun pala 
Ekstraksi Daun Pala (Lisnawati, 2014)

Ekstraksi dilakukan menggunakan metode maserasi menggunakan pelarut akuades. Menimbang bubuk daun pala sebanyak 100 gram, kemudian memasukkan ke dalam Erlenmeyer $2000 \mathrm{~mL}$ lalu menambahkan $1000 \mathrm{~mL}$ aquadest (perbandingan sampel dan pelarut 1:10). Menyimpan campuran selama 1 x 24 jam sambil sesekali diaduk, kemudian menyaring menggunakan penyaring vakum. Memisahkan filtrat yang diperoleh dengan pelarutnya menggunakan rotary vakum evaporator sehingga didapatkan ekstrak kental daun pala.

\section{Pembuatan Campuran Polieugenol dan Ekstrak Daun Pala (Indrasti et al., 2012)}

Campuran polieugenol dan ekstrak daun pala dibuat dengan perbandingan $1: 1(b / b)$ dengan cara menimbang kedua bahan tersebut, lalu dicampurkan dan dilarutkan menggunakan pelarut DMSO

Uji Aktivitas Antibakteri Campuran Polieugenol Dan Ekstrak Daun Pala dengan Metode Sumur Difusi (Darmawati, 2009)

Pada pengujian aktivitas antibakteri menggunakan metode sumur difusi. Mencampurkan Media Nutrient Agar (NA) sebanyak $25 \mathrm{~mL}$ dengan $25 \mu \mathrm{L}$ suspensi bakteri uji (Straphylococcus aureus dan Eschericia coli), dihomogenkan lalu dituang dalam cawan petri steril dan dibiarkan sampai memadat. Setelah itu membuat sumur yang berdiameter $6 \mathrm{~mm}$ menggunakan alat pelubang. Cawan pertama berisi 2 lubang atau sumur (lubang pertama untuk kontrol positif berupa kloramfenikol $1 \%$ dan lubang kedua berisi kontrol negatif berupa DMSO). Cawan kedua berisi 3 lubang atau sumur (lubang pertama dan kedua berisi campuran polieugenol dan ekstrak daun pala $1 \% 2 \%$, sedangkan lubang ketiga berisi ekstrak kental daun pala), dan cawan ketiga terdapat 3 lubang atau sumur (lubang pertama kedua da ketiga berisi campuran polieugenol dan ekstrak daun pala $3 \% 4 \%$ dan $5 \%$ ). setiap sumur diisi dengan campuran ekstrak dan kontrol sebanyak $50 \mu \mathrm{L}$, kemudian diinkubasi selama 24 jam pada suhu $37^{\circ} \mathrm{C}$, selanjutnya diamati dan diukur diameter zona hambatnya menggunakan jangka sorong.

\section{HASIL DAN PEMBAHASAN}

\section{Poleugenol Hasil Sintesis}

Polieugenol yang dihasilkan dari proses polimerisasi berbentuk padat dan berwarna hitam keunguan. Hasil tersebut sesuai dengan penelitian Ainun (2017) yang mendapatkan polieugenol yang berbentuk padat dan memiliki warna hitam keunguan. Sintesis polieugenol pada penelitian ini menggunakan polimerisasi kationik antara eugenol dan katalis $\mathrm{H}_{2} \mathrm{SO}_{4}-\mathrm{CH}_{3} \mathrm{COOH}$, proses terjadinya polimerisasi ditandai dengan terbentuknya asap putih tebal yang diduga berupa katalis $\mathrm{H}_{2} \mathrm{SO}_{4}$ dan polimer melekat pada dinding gelas kimia berupa padatan. 


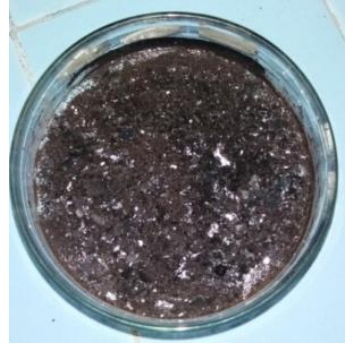

Gambar 1 Polieugenol Hasil Pemurnian

Pada proses pemurnian, polieugenol dilarutkan dalam dietil eter dan akuades, sehingga terbentuk dua lapisan larutan, larutan atas merupakan dietil eter dan polieugenol yang tidak larut dalam air dan lapisan bawah berupa air dan katalis. Menurut Lawrence dan Piel (2004) Kerapatan jenis dietil eter lebih kecil dibandingkan air, sehingga lapisan eter biasanya berada pada lapisan atas. Selain itu, penggunaan dietil eter dikarenakan sifatnya yang nonpolar dan larutan tidak akan tercampur dengan air, sehingga proses pemurnian lebih mudah dilakukan. Hasil dari pemurnian diperoleh rendemen polieugenol $72,027 \%$ berbentuk padat berwarna hitam kecoklatan (Gambar 1)

Berat molekul polieugenol hasil pemurnian didapatkan dengan menggunakan metode viskometer sebesar $2.18 \times 10^{7} \mathrm{~g} / \mathrm{mol}$. Berat molekul yang didapatkan berbeda dengan hasil penelitian sebelumnya. Pada Penelitian Hikmah (2017) menghasilkan polieugenol dengan berat molekul sebesar $776.247,12 \mathrm{~g} / \mathrm{mol}$. Menurut Chance et al., (1993) derajat polimerisasi berdasarkan berat molekulnya terdiri dari berat molekul rendah yang berkisar 500-5000 g/mol, berat molekul sedang berkisar 5000-
$10000 \mathrm{~g} / \mathrm{mol}$ dan berat molekul tinggi $>10000 \mathrm{~g} / \mathrm{mol}$. Sehingga polimer yang diperoleh termasuk polimer bermolekul tinggi. Berat molekul suatu polimer tergantung pada jumlah unit-mer yang berulang dikali dengan berat molekul unitmer yang berulang, berat molekul yang dihasilkan dapat berkisar dari ribuan hingga jutaan unit tergantung pada proses preparasinya (Hikmah, 2017).

\section{Aktivitas Antibakteri Campuran Polieugenol dan Ekstrak Daun Pala Terhadap Staphylococcus aureus dan Escherichia coli}

Hasil pengujian aktivitas antibakteri polieugenol dengan penambahan esktrak daun pala menunjukkan bahwa campuran tersebut memiliki aktivitas antibakteri selain pada larutan campuran, pada ekstrak daun pala juga memiliki aktivitas antibakteri terhadap S.aureus dan E.Coli yang ditunjukkan dengan terbentuknya zona bening pada medium agar padat NA. Hasil pengukuran zona hambat esktrak daun pala dan masing-masing konsentrasi campuran polieugenol dan ekstrak daun pala terhadap bakteri S.aureus dan E.Coli dapat dilihat pada Tabel 1

Tabel 1. Hasil Pengukuran zona hambat bakteri gram positif (S.aureus) dan bakteri gram negatif (E.coli)

\begin{tabular}{cccc}
\hline \multirow{2}{*}{ Bahan Uji } & \multirow{2}{*}{ Konsentrasi } & \multicolumn{2}{c}{ Zona hambat $(\mathrm{mm})$} \\
\cline { 3 - 4 } & & S.aureus & E.coli \\
\hline Ekstrak & \multirow{2}{*}{$100 \%$} & 22,09 & 35,40 \\
daun pala & & & \\
\hline Campuran & $1 \%$ & 15,06 & 17,50 \\
polieugenol & $2 \%$ & 16,93 & 18,22 \\
dan ekstrak & $3 \%$ & 18,51 & 18,90 \\
daun pala & $4 \%$ & 19,69 & 19,05 \\
kontrol (-) & $5 \%$ & 20,99 & 19,45 \\
Kontrol (+) & $1 \%$ & 0 & 0 \\
\hline
\end{tabular}


Berdasarkan Tabel 1, diameter zona hambat yang dihasilkan campuran polieugenol dan ekstrak daun pala semakin tinggi seiring dengan bertambahnya nilai konsentrasi campuran. Hal ini sesuai dengan penelitian Kumala (2008) dalam Andries et al. (2014) menyatakan bahwa konsentrasi ekstrak mempengaruhi kecepatan difusi zat berkhasiat, yaitu semakin besar konsentrasi ekstrak maka makin besar pula aktifitas antibakteri yang dihasilkan sehingga menghasilkan diameter zona hambat yang makin luas. Selain itu, kontrol positif yang digunakan yaitu kloramfenikol menghasilkan zona hambat sebesar 45,95 mm terhadap S.aureus, sedangkan E.Coli sebesar 45,33 mm, nilai yang dihasilkan termasuk pada aktivitas antimikroba yang tergolong kuat, dikarenakan kloramfenikol merupakan golongan antibiotik yang berspektrum luas dengan kekuatan daya hambat yang tinggi dalam menghambat dan membunuh bakteri (Alviana, 2016). Levinson (2004) dalam Alviana (2016) menjelaskan kloramfenikol mampu mengikat subunit ribosom sel mikroba target dan menghalangi aktifitas enzim peptidyltransferase,sehingga menghambat pembentukan ikatan peptida dan sintesis protein. Sedangkan kontrol negatif yang digunakan yaitu DMSO yang tidak menunjukkan zona hambat. Hal ini berarti DMSO merupakan pelarut yang baik, dikarenakan dapat melarutkan tanpa memberikan pengaruh terhadap pertumbuhan bakteri uji, sehingga respon kematian bakteri benar-benar berasal dari larutan uji yang digunakan (Marliana et al., 2005). Hasil uji aktivitas antibakteri campuran polieugenol dan ekstrak daun pala menunjukkan aktivitas tertinggi pada konsentrasi $5 \%$ yaitu $20,99 \mathrm{~mm}$ terhadap S.aureus dan 19,45 terhadap E.coli, hal ini menunjukkan bahwa aktivitas antibakteri campuran polieugenol dan ekstrak daun pala lebih efektif pada bakteri S.aureus yang merupakan bakteri gram positif. Perbandingan tersebut dapat dilihat pada (Gambar 1).

Pada uji aktivitas antibakteri ekstrak daun pala menghasilkan daya hambat sebesar 22,09 mm terhadap S.aureus dan 35,40 mm terhadap E.coli. Ekstrak daun pala mengandung senyawa metabolit sekunder yang berupa flavonoid, triterpenoid, tanin dan alkaloid. Robinson (1995) menyatakan bahwa alkaloid memiliki kemampuan sebagai antibakteri dengan cara mengganguu komponen penyususn peptidoglikan pada sel bakteri, sehingga menyebabkan lapisan dinding sel tidak terbentuk secara utuh dan menyebabkan kematian pada sel bakteri, terpenoid juga berpotensi sebagai antimikroba yaitu bekerja merusak dinding sel bakteri dengan cara mengganggu komponen peptidoglikan sel bakteri sehingga lapisan dinding sel bakteri mengalami kerusakan. Dwidjoseputro (2005) juga menyatakan bahwa golongan flavonoid berfungsi sebagai antibakteri dengan cara membentuk senyawa 
kompleks terhadap protein ekstraseluler yang dapat mengganggu integritas membran sel bakteri. Efek antibakteri yang dihasilkan tanin antara lain melalui reaksi dengan membran sel, inaktivasi enzim, dan destruksi atau inaktivasi fungsi materi genetik (Akiyama, et al.., 2001). Dari hasil tersebut menunjukkan bahwa ekstrak daun pala memiliki daya hambat tertinggi terhadap E.Coli dibandingkan S.aureus.

Menurut Nithiya dan Vijayalakshmi (2005) bakteri gram positif memiliki struktur dinding sel dengan lebih banyak peptidoglikan, sedikit lipid dan dinding sel mengandung polisakarida (asam teikoat). Asam teikoat adalah jenis polimer yang memiliki kelarutan tinggi dalam air dan berfungsi sebagai transport ion positif untuk keluar atau masuk. Kelarutan asam teikoat dalam air menunjukkan bahwa dinding sel bakteri gram positif bersifat polar. Sementara itu, bakteri gram negatif banyak mengandung senyawa lipid, sedikit peptidoglikan, dan membran luar berupa bilayer yang berfungsi sebagai pertahanan selektif senyawa-senyawa yang keluar masuk sel yang dapat menyebabkan efek toksik. Membran luarnya terdiri dari fosfolipid pada lapisan dalam, dan lipopolisakarida pada lapisan luar yang tersusun atas lipid nonpolar. Perbedaan struktur dinding sel bakteri inilah yang menentukan aktivitas senyawa antibakteri.

Pada penelitian Al-Milda (2018) uji aktivitas antibakteri polieugenol 5\% terhadap S.aureus sebesar 22,55 $\mathrm{mm}$ dan E.coli sebesar $19.21 \mathrm{~mm}$, hasil tersebut menunjukkan nilai daya hambat tertinggi terhadap S.aureus dibandingkan dengan E.coli. Perbedaan daya hambat yang dihasilkan ekstrak daun pala dan polieugenol 5\% terhadap S.aureus dan E.coli dapat dilihat pada (Gambar 2).

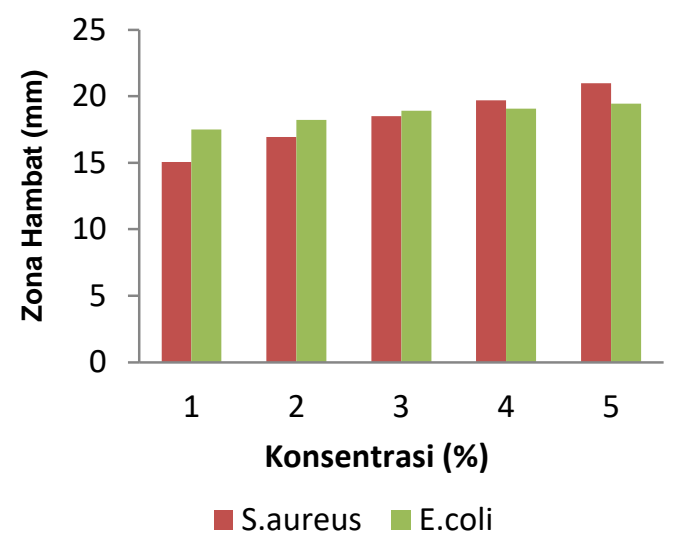

Gambar 2. Hasil Pengukuran Zona Hambat Polieugenol dengan Penambahan Ekstrak Daun Pala Terhadap bakteri S.aureus dan E.coli

Hasil penelitian juga menunjukkan bahwa nilai daya hambat yang dihasilkan campuran polieugenol dengan ekstrak daun pala pada konsentrasi $1 \% 2 \%$ dan $3 \%$ menghasilkan nilai daya hambat tertinggi pada E.coli, namun pada konsentrasi $4 \%$ dan $5 \%$ nilai daya hambat terhadap bakteri S.aureus naik dibandingkan dengan nilai daya hambat terhadap E.coli (Gambar 2). Polieugenol yang terbentuk dari monomer eugenol memiliki aktivitas antibakteri, eugenol termasuk dalam kelompok fenilpropen, kelompok hidroksil bebas yang terdapat pada eugenol dapat memberikan aktivitas antimikroba (Laekeman et al., 1990). Gill 
dan Holley (2006) menjelaskan gugus hidroksil bebas pada eugenol berkontribusi terhadap efek penghambatan pertumbuhan mikroba karena mengikat dan mempengaruhi sifat protein sehingga dapat menghambat aktivitas beberapa enzim seperti ATP yang dapat membunuh sel pada konsentrasi tinggi, sehingga energi yang dibutuhkan untuk pemulihan sel terganggu. Sebuah penelitian yang dilakukan Oyedemi et al (2009) mengungkapkan terjadinya lisis pada sel beberapa bakteri gram positif dan gram negatif yang diinduksi oleh eugenol dengan merusak dinding sel dan membran sehingga menyebabkan kebocoran pada sel mikroba.

Berdasarkan hasil uji statistik one way ANOVA menujukkan nilai daya hambat S.aureus yang dihasilkan dengan berbagai konsentrasi campuran polieugenol dan ekstrak daun pala menghasilkan nilai signfikan $0,00<\alpha$ $(0,05)$. Sehingga dilanjutkan dengan uji Duncan yang menunjukkan perbedaan nyata terhadap nilai daya hambat yang dihasilkan berbagai konsentrasi campuran polieugenol dan ekstrak daun pala yang diujikan. Sedangkan hasil uji statistik nilai daya hambat E.coli yang dihasilkan dengan berbagai konsentrasi campuran polieugenol dan ekstrak daun pala menunjukkan nilai signifikan $0,53>\alpha$ $(0,05)$. Uji Duncan menunjukkan tidak ada perbedaan nyata terhadap nilai daya hambat yang dihasilkan berbagai konsentrasi campuran polieugenol dan ekstrak daun pala yang diujikan.

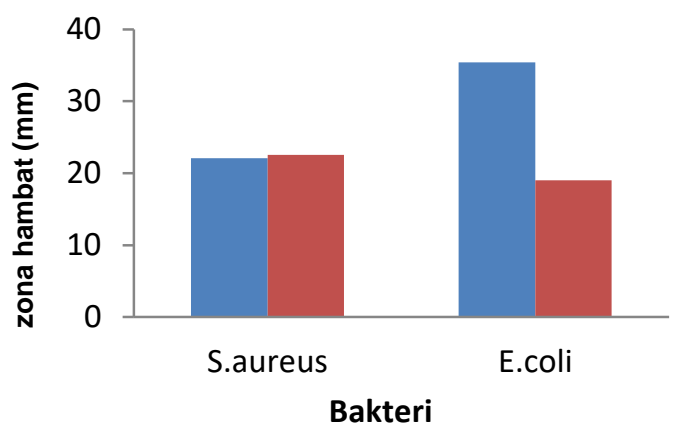

Ekstrak daun pala polieugenol 5\%

Gambar 2. Hasil Pengukuran Zona Hambat ekstrak daun pala dan Polieugenol 5\% (Gilang, 2018) Terhadap S.aureus dan E.coli

Menurut Davis dan Stouth (1971) bahwa aktivitas antimikroba yang menghasilkan penghambantan $20 \mathrm{~mm}$ dinyatakan aktivitas antimikroba yang tergolong sangat kuat, sedangkan pada penghambatan 10-20 $\mathrm{mm}$ bersifat kuat. Apabila diameter penghambatan yang dihasilkan antara 5-10 mm, maka aktivitas antimikrobanya tergolong sedang dan diameter penghambatan $5 \mathrm{~mm}$ merupakan aktivitas antimikroba lemah. Ekstrak daun pala dan poliugenol 5\% terhadap S.aureus dan E.coli termasuk antimikroba kuat. Sedangkan nilai daya antibakteri campuran polieugenol dan ekstrak daun pala terhadap S.aureus pada konsentrasi $1 \% \quad 2 \% \quad 3 \% \quad 4 \%$ termasuk aktivitas antibakteri yang tergolong kuat, dan pada konsentrasi 5\% termasuk antibakteri yang sangat kuat. Daya antibakteri yang dihasilkan campuran polieugenol dan ekstrak daun pala terhadap E.coli pada 
konsentrasi $1 \% \quad 2 \% \quad 3 \% \quad 4 \%$ dan $5 \%$ tergolong sebagai aktivitas antimikroba yang tergolong kuat.

\section{KESIMPULAN}

Berdasarkan hasil penelitian yang telah dilakukan, dapat disimpulkan bahwa Penambahan esktrak daun pala terhadap aktivitas antibakteri polieugenol menghasilkan kenaikan nilai daya hambat terhadap bakteri E.coli, namun kenaikan nilai yang dihasilkan tidak signifikan terhadap nilai daya hambat yang dihasilkan polieugenol tanpa penambahan ekstrak daun pala. Sedangkan nilai daya hambat yang dihasilkan terhadap bakteri S.aureus mengalami penurunan dibandingkan penggunaan polieugenol tanpa penambahan ekstrak daun pala.

\section{DAFTAR PUSTAKA}

Agusta, A. 2000. Minyak Atsiri Tumuhan Tropika Indonesia. Bandung: ITB.

Akiyama, H., Fujii K, Yamasaki O, Oono T, Iwatsuki K. 2001. Antibacterial Action of Several Tannins Agains Staphylococcus aureus. Journal of Antimicrobia Cahemotherapy. 48 : 487-91.

Alviana. N. 2016. Uji Efektivitas Antibakteri Ekstrak Etanol Daun Krisan (Chrysanthemum morifolium Syn. Dendrathema grandiflora) Terhadap Staphylococcus aureus dan Escherichia coli. [Tesis]. Yogyakarta: Universitas Atma Jaya Yogyakarta.

Al-Milda, G. 2018. Uji Aktivitas Antibakteri Polieugenol Berat Molekul Tinggi Terhadap Bakteri Staphylococcus aureus dan Escherichia coli.
[Skripsi]. Palu: Jurusan Kimia FMIPA, Untad.

Andries R.J, Gunawan P.N., Supit, A. 2014. Uji Efek Antibakteri Ekstrak Bunga Cengkeh Terhadap Bakteri Streptococcuc mutans Secara In Vitro. Jurna e-GiGi. 2(2).

Darmawati, S. 2009. Keanekaragaman Genetik Salmonella thypii. Journal kesehatan. 2 (1) 28-32.

Davis dan Stout. 1971. Disc Plate method of microbiological antibiotic essay. Journal Of Microbiology. 22 (4).

Dwidjoseputro. 2005. Dasar-Dasar Mikrobiologi. Djambaran; Jakarta.

Ginting, B., Barus, T., Marpau, L., dan Smanjuntak, P. 2013. Isolasi Total Flavonoid Daun Pala. Seminar Nasional Kimia 2013. Medan: Universitas Sumatera Utara.

Hikmah, S A. 2017. Sintesis dan Karakterisitik Polieugenol dari Eugenol Menggunakan Katalis $\mathrm{H}_{2} \mathrm{SO}_{4}-\mathrm{CH}_{3} \mathrm{COOH}$. [Skripsi]. Palu: FMIPA UNTAD.

Indrasti, N.S, Suprihatin, dan Setiawan W.K. 2012. Kombinasi kitosanekstrak pala sebagai bahan antibakteri dan pengawet alami pada filet kakap merah (Lutjanus sp.). Jurnal Teknologi Industri Pertanian. 22 (2):122-130

Josodiwondo, S., U.C. Warsa, Soebiandrio dan Soedarmono. 1996, Perkembangan Kuman Terhadap Antimikroba Saat Ini, Majalah Kedoktean Indonesia. 46(9); 467.

Lisnawati, 2004. Aktivitas Antioksidan Ekstrak Daun Kelor (Moringa Oleifera L) Dari Berbagai Tingkat Kepolaran Pelarut. [Skripsi]. Palu: Fakultas Matematika Dan IImu 
Pengetahuan Alam. Universitas Tadulako.

Marliana SD, Suryanti V, dan Suyono. 2005. Skrining Fitokimia dan Analisis Kromatografi Lapis Tipis Komponen Kimia Buah Labu Siam (Sechium edule Jacq. Swartz.) dalam Ekstrak Etanol. Biofarmasi. 3(1):26-31.

Nithiya T, and Vijayalakshmi R. 2015. Antimicrobial activity of fruit extract of Annona squamosa L. WJPPS. 4(5):1257-67.

Nurdjannah, N. 2007. Teknologi Pengolahan Pala. Bogor: Badan Penelitian dan Pengembangan Pertanian.

Pelczar, M.J. dan Chan, E. C. S., 1988, Dasar-dasar Mikrobiologi Jilid 1, Jakarta: UI Press.

Rastuti, U., Widyaningsih, S., Kartika, D., dan Ningsih, D.R. 2013. Aktivitas Antibakteri Minyak Atsiri Daun Pala Dari Banyumas Terhadap Staphylococcus aureus dan Escherichia coli Serta Identifikasi Senyawa Penyusunnya. Molekul. 2(2).

Robinson T. 1995, Kandungan Organik Tumbuhan Tingkat Tinggi, Bandung: ITB.

Saputra, D.A. 2016. Uji Aktivitas Antibakteri Senyawa Polieugenol Terhadap Staphylococcus aureus dan Escherichia coli. [Tesis]. Surakarta: FMIPA Universitas Sebelas Maret.

Sastrohamidjojo, H. 1981. A Study of Some Indonesian Essential Oils. Yogyakarta: FMIPA Universitas Gadjah Mada.

Sudarlin dan Haryadi, W. 2015. Polimerisasi Eugenol Minyak Daun Cengkeh Hasil Redistilasi,
Ekstraksi, dan Fraksinasi Menggunakan Katalis Asam Sulfat Pekat. Jurnal Kimia VALENSI: Jurnal Penelitian dan Pengembangan IImu Kimia, 3(1): 50-58.

Suirta, I.W., N.L. Rustini, dan T.I. Prakasa. 2012. Sintesis Polieugenol Dari Eugenol Dengan Katalis Asam Nitrat Pekat Dan Media Natrium Klorida. Jurnal Kimia, 6 (1): 37-46.

Sulistyo, 1971, Farmakologi dan Terapi. Yogyakarta: EKG. 